\title{
Germany's Options in Afghanistan
}

\section{Timo Noetzel and Thomas Rid}

For the past eight years, Germany's contribution to the stabilisation of Afghanistan has been limited by political factors in Germany and military factors in Afghanistan. Several trends in 2009 have added to the pressures on German policy, including an increase in violence in Afghanistan's northern provinces, such as Kunduz, where Germany is active; a lack of political progress in Kabul; the destabilisation of Pakistan; and renewed efforts by the Obama administration and a couple of hardened allies to quell the Taliban insurgency. Although the greater instability in Kunduz - and across Afghanistan - increases both the need to act decisively and the risks associated with political paralysis in Berlin, the next German government is likely to adapt its policies only marginally, instead of leaping into action as the new US administration has done.

Two simultaneous developments explain this inertia, one in Germany and one in the field. Germany's military mission in Afghanistan has become increasingly politicised in the eight years since it was launched. Political and ideological differences between parties and even between ministries are becoming more pronounced, not less. This trend narrows the room for manoeuvre and stalls the strategic debate.

At the same time, in northern Afghanistan, where new NATO supply lines have increased the operational stakes for both sides, the Bundeswehr has been engaged in increasingly aggressive combat operations against ever-

Timo Noetzel is a Research Group Leader at the Centre of Excellence at Konstanz University and a Fellow of the Stiftung Neue Verantwortung, Berlin. Thomas Rid is a Public Policy Scholar at the Woodrow Wilson Center and an Adjunct Professor at the School of International Service, American University. 
bolder insurgents. This recent exposure to a new level of operational stress puts the German armed forces under added pressure to learn and adapt to a counter-insurgency environment. As in the United States and Britain, mid-level officers are bringing back valuable experiences and lessons from their tours.

The result of these two contrary but related trends is stalemate. On the one hand, an already sceptical Bundestag is under pressure from the public to scale back Germany's contribution, pressure that is also strongly felt among senior civilian and military leaders in the ministry of defence. On the other hand, the executive branch, particularly the chancellery and the foreign office, is feeling allied pressure to pull more weight, and field commanders in Afghanistan are determined to face up to a bolder enemy just as NATO's other fighting armies are. In the absence of strong and charismatic leadership in the field of security policy, the result is inertia: no matter the outcome of coalition negotiations, Germany's Afghanistan policy is poised to remain on its present track, with only modest adjustments. Berlin will, by default, react to Washington's strategic lead, though it will not necessarily do what the Obama administration wants it to. This passivity is remarkable given that Germany's stakes in Afghanistan are potentially even higher than those of the United States: continued violence and occupation in Afghanistan will fuel Muslim radicalisation in Europe more than in America. As Afghanistan backfires, Europe will be hit harder.

\section{Germany in Afghanistan}

Germany sees itself as tightly connected to Afghanistan. The relationship between the two countries goes back at least to the First World War when, in 1915, a famed military mission under Werner Otto von Hentig's leadership tried to rouse Emir Habibullah's resistance against the British in India. ${ }^{1}$ Diplomatic relations between the two countries were established in 1919. Almost 90,00o people of Afghan extraction now live in Germany and, to this day, many Afghans see Germans as fellow Aryans, creating the occasional awkward moment for German officers deployed there. The most visible, recent embodiment of the connection between the two countries was a conference at the end of 2001 on Petersberg mountain, from which emerged 
the so-called Bonn Agreement attempting to establish a foundation for Afghanistan's political future.

Germany's contribution to the stabilisation of Afghanistan falls into three broad areas, each handled by different ministries and agencies. Firstly, the Ministry for Economic Cooperation and Development (BMZ) is in charge of economic assistance and development. Berlin has increased its financial contribution to Afghanistan's civil reconstruction from $€ 80$ million per year in 2002 to approximately $€_{200 m}$ per year in 2008 , excluding the defence budget. By 2010, Germany will have spent $\epsilon_{1.2}$ billion on civil reconstruction in Afghanistan. ${ }^{2}$ This development assistance is focused on four areas: the energy sector, drinking-water supply, sustainable economic development and job creation, as well as basic education. Berlin is Afghanistan's fourthlargest donor, behind the United States, Britain and Japan. Germany's economic assistance is focused on the north of the country and on the capital, Kabul. The BMZ is often reluctant to cooperate openly with the army, for reasons of both bureaucratic culture and, allegedly, security.

Secondly, Germany is contributing to the training and establishment of an Afghan police force. Because of Germany's federal structure, the national Ministry of the Interior shares responsibility for the police mission with The number of German police on the ground is worryingly the 16 state-level interior ministries. In addition, since June 2007, EUPOL, a European agency, has been tasked with the coordination of police training in Afghanistan, adding another layer of bureaucratic complexity. At the same time, Germany maintains a bilateral police-training mission. From 2002 to 2008 , the annual budget for police reform was a mere $€_{12 m}$, although last year this was tripled to almost $\epsilon_{3} 6 \mathrm{~m}^{3}$. Germany's staff contribution has been even more modest. Since April 2002, an average of 40 police trainers at a time have manned offices located mainly in Kabul, Mazar-e-Sharif, Kunduz City and Faisabad; currently, about 60 are deployed. By summer 2009, the number of German police trainers was supposed to reach 100, but it has proved difficult to fill this many positions. ${ }^{4}$ Seen against the background of a heavy administrative structure, the number of German police boots on the ground is worryingly small; moreover, these officers rarely leave their secure compounds, focusing 
mainly on 'consulting' work for the Afghan government, not hands-on police training. Some allies see the police-training mission, and Germany's initial role as the lead nation, as a flat-out failure, or even counterproductive. ${ }^{5}$

Finally, the Ministry of Defence is responsible for the military component of Germany's contribution. After the United States and Britain, Germany is the third-largest troop contributor to NATO's Afghanistan mission. Germany has gradually increased its troop limits for Afghanistan from 1,200 in 2001 to 2,250 in 2003; to 3,500 in 2007; and eventually to 4,500 in 2008 . The chancellery is hoping to further increase the ceiling in December 2009, when the mandate will have to be reauthorised by the Bundestag based on a suggestion from the government. Forces are deployed to garrisons close to Mazar-e-Sharif, Kunduz City, Faisabad and some smaller outposts in districts of Kunduz and Takhar provinces. Camp Marmal, a large Forward Support Base outside of Mazar-e-Sharif, houses the Command Headquarters of Regional Command North, the Quick Reaction Force, and all the logistical, medical, airpower and support capabilities of the International Security Assistance Force (ISAF) in northern Afghanistan. All in all, 2,000 soldiers are based there. 700 soldiers are stationed in the Provincial Reconstruction Team (PRT) in Kunduz City and around 400 in the Faisabad PRT. The two teams are led jointly by officials from the German Foreign Ministry and the Ministry of Defence. The rationale behind this double-hatted structure is to guarantee effective collaboration between civilian and military actors and to provide a security shield for civilian workers. The overall strategic coordination authority lies with the German Foreign Office.

In all areas - diplomacy, economic aid, police training and military support - Germany has significantly increased its commitment in the last year. Yet, mostly because of a deteriorating security situation, it is the security sector and the military component that matter most. And it is also in the military sphere where, in many ways, German legal frameworks and standard operating procedures have to be adapted most urgently.

\section{Legal limitations}

The current mandate for the International Security Assistance Force, by law, limits the Bundeswehr's contribution not only numerically but also geo- 
graphically. Its area of operation is ISAF's northern region, which includes the provinces of Faryab, Sar-e Pol, Jowzjan, Balkh, Samangan, Baghlan, Kunduz, Takhar and Badakhshan. The mandate allows only limited operations beyond this area. The exceptions are Medevac missions; air transport; psychological operations; the use of Tornado reconnaissance airplanes, provided they are not used for close air support; and - theoretically - the deployment of combat forces to provide emergency relief 'in extremis' to other allied forces in the country at the request of the overall ISAF commander. In addition, some signal and communications units have been deployed to southern Afghanistan for a few years now. The objective, according to the mandate, is to 'stabilise and reconstruct' Afghanistan with the ultimate aim of creating 'a state ... that meets the basic requirements of political legitimacy and has sufficiently effective institutions of security and justice in order to defend itself against remaining threats from militant opposition, organized crime, and terrorism.' Afghanistan, the document adds, 'must not again become a haven for international terrorism'.

Broad limitations and some caveats are politically necessary. But legal restrictions heavily restrain the German army's ability to operate according to multinational requirements. A much-discussed example is the so-called pocket card, a small instructional handout that contains the rules of engagement in simple terms for every German soldier. The rules are designed to minimise the use of force and firepower, raising concerns that the card might unreasonably limit troops' ability to react to and shape tactical situations, and that it might even costs lives. Until recently, one item on the card instructed soldiers to warn potential adversaries: 'United Nations -Stop, or I will fire!' To make sure the message got through, the card provided a Pashto translation: 'Melgäro Mellatuna - Dreesch, ka ne se dasee kawumm!' The warning was supposed to be repeated if necessary. Until April 2009 German ISAF forces were allowed to use force only in self-defence, when under fire. As a result, during a commando raid a few months earlier, German Special Operations Forces could do nothing but watch a high-value target slip away: the insurgent managed to evade a capture operation by breaking through a security cordon around a building - and only a sniper could have stopped the fleeing man, which the rules of engagement at that time did not permit. 
The pocket card's phrasing, and suggested adaptations to operational realities, have been discussed at the highest levels of German politics. The result is that soldiers are confused and uncertain not only about operational risks, but about the legal risks they are taking in combat situations.

A second example makes this clear: the routine involvement of a public prosecutor, the Staatsanwaltschaft, in military affairs. Whenever a civilian abroad, of any nationality, is killed in a situation involving a German soldier, the public prosecutor starts an investigation into the incident. Usually the Potsdam public prosecutor is responsible for opening the inquiry, as the Bundeswehr's operational command headquarters, the Einsatzfuihrungskommando, is located in the Potsdam Norwegian units were forced to retreat region. The case is then passed on to the public prosecutor of the respective soldier's home region. But in an irregular war like Afghanistan, the line between civilfrom the front lines every day ians and combatants is difficult to draw. The result is 'grotesque', in the words of a senior political operator in the chancellery: ${ }^{7}$ in every instance where an insurgent is killed, a regional public prosecutor somewhere in Germany, usually without any expertise in such situations, ends up having to deal with the case, often dragging out the proceedings against soldiers who did nothing but their job. Even attempts to create a central public-prosecution authority for foreign military operations have so far been unsuccessful. Such an office might be too sympathetic to the military, critics say.

A combination of limited capabilities and legal restraints can create serious operational impairments for German forces in the field. During Operation Harekate Yolo II in late 2007 , for example, German medical-evacuation helicopter units that were assigned to provide back-up to Norwegian combat units fighting insurgents had to return to base before sundown every day because they lacked night-flight-capable helicopters and had to conform with standard peace-time regulations governing military air operations in Germany. This meant they had to leave by mid afternoon during the Afghan November. As a result, Norwegian units were forced to retreat from the front lines every day, making it impossible to tie down insurgent forces. ${ }^{8}$ 


\section{Public support}

To adapt or change these legal frameworks, political and legislative support is necessary. But the public is not only unprepared to give that backing, their support for the war has gone from weak to weaker. In late spring 2009, the military situation in northern Afghanistan began to deteriorate. 'For the first time, there is a kind of military plan behind [the enemy's attacks]', Bundeswehr Chief of the General Staff Wolfgang Schneiderhan commented after one particularly fierce Taliban attack. ${ }^{9}$ The day before, 29 April 2009, saw the first German soldier to be killed in a fire-fight, an action in which nine others were also wounded. Franz Josef Jung, the defence minister, publicly warned that the Taliban was eyeing the upcoming German federal elections and would be trying to influence public opinion. As of 24 August, 33 German soldiers had lost their lives in Afghanistan, and each casualty is highly publicised in Germany. ${ }^{10}$ In the past, US and German intelligence services have repeatedly warned that the Taliban would try to influence the decisions of the German parliament.

Such an attempt could have some chance of success, as German public support for the operation in Afghanistan is shaky. Asked whether the mission was 'wrong' or 'right', $62 \%$ of Germans replied that it was wrong that their army was stationed in Afghanistan. ${ }^{11}$ When the Bundestag voted to extend the mandate in 2008 from 3,500 to 4,500 soldiers, polls showed that $74 \%$ of Germans were against this, with only $23 \%$ in favour. ${ }^{12}$ In a remarkable poll in 2008, one question inquired whether Germany should do more in the campaign against terror if a newly elected President Barack Obama asked them to; $79 \%$ said 'no' and only $14 \%$ 'yes'. ${ }^{13}$ In a Forsa poll, $58 \%$ of respondents wanted Germany to end the Bundeswehr operation in Afghanistan and withdraw, while only $36 \%$ supported a continuation of the ISAF operation. ${ }^{14}$ When broken down by party preference, a surprising picture emerged: in contrast to the mainstream parties' voting behaviour in the Bundestag, where the mandate is supported by all parties except the far left, support for the war among the population was low across the political spectrum. Of all voters, those identifying with the Green Party were the most likely to support the Afghanistan operation.

Former Chancellor Gerhard Schröder's minister of defence, Peter Struck, coined the memorable phrase, 'Germany has to be defended in the Hindu 
Kush too'. Parliamentarians of all parties still find the line useful, believing it has traction. Yet the public never fully warmed to the policy, neither on the right nor on the left. Increasing criticism on the right is particularly remarkable. When a new and controversial memorial for fallen German soldiers was unveiled earlier in 2009, Otto Depenheuer, a conservative law professor, plainly asked in the Frankfurter Allgemeine Zeitung: what are we defending? In his view, it may be a violation of Germany's basic law to send Bundeswehr soldiers to die in far-flung places for 'peace, law, and freedom' - as the memorial's inscription has it - where the connection to the peace, rule of law and freedom in Germany is questionable. Depenheuer suggested amending the memorial's wording to read 'for peace, law, and freedom of the German fatherland'. ${ }^{15}$

Indeed, the Bundeswehr's efforts in Afghanistan are not seen by the German electorate as defensive acts, but rather as a reconstruction and stabilisation effort. Germany is not taking part in the operation to serve its own interests, but because it carries part of the international community's responsibility to fix a damaged country. This ambiguity is reflected in the government's treatment of the word Krieg. 'War' is a loaded word in German. It still triggers memories of large-scale invasions, air-raid sirens and bombs raining down on major cities. The notion that Krieg should somehow be in the interest of the population among whom it is waged, a central notion of US counter-insurgency doctrine, has no resonance in Germany. Yet most Germans, despite the defence minister's declaration to the contrary, think that the Bundeswehr is engaged in a Kriegseinsat, a war, not just a humanitarian operation. The government argues that Germany is engaged in humanitarian self-defence, whereas the population questions how the war is tied to the national interest. ${ }^{16}$ Still, things are changing slowly: even Jung, the defence minister, has started to refer to combat fatalities as Gefallene, or fallen, an equally heavy term in German. And on 6 July 2009 the German government, for the first time since the Second World War, awarded a medal for bravery to four soldiers, modelled on the Iron Cross.

In Germany, a parliamentary system with strong federal elements guarantees rapid feedback from voters to decision-makers. Foreign policy traditionally has not been a major campaign issue, but since the arrival of 
a fifth party, Die Linke, composed largely of former communists from the East, political majorities in general have become more difficult to establish, meaning that every subject with the potential to shift tight margins is relevant in election campaigns. And Germany's many levels of government ensure that election campaigns take place all year round. 'Foreign policy only has an effect on the margins', argues Hellmut Königshaus, a Free Democratic Party (FDP) politician on the international-development affairs committee. 'But margins count in our system.' ${ }^{17}$ Yet those parliamentarians who actually capitalise on their foreign-policy position are the exception, not the rule. Willy Wimmer, one of the few opponents of the Afghanistan mission in the Christian Democratic Union (CDU) Party, believes he won his district because of his criticism of foreign policy. He vehemently opposes the war in Afghanistan and even sued the government on constitutional grounds in Germany's constitutional court, the Bundesverfassungsgericht. This is not to suggest that he does not understand Afghanistan: behind Wimmer's desk is a picture of him with Ahmed cannot count Shah Massoud, the legendary Northern Alliance leader killed by al-Qaeda shortly before $x x$ September 2001 . But on the local campaign trail, Wimmer says, conservatives 'only get beat up' for their position on Afghanistan. ${ }^{18}$ on all their members

Other politicians feel the pressure as well: 'The more casualties, the more Afghanistan will be a topic on the campaign trail', said Rolf Mützenich, an Social Democratic (SPD) parliamentarian. ${ }^{19}$ Winfried Nachtwei, one of the Green Party's senior defence experts and a supporter of the operation who has been to Kabul many times, agrees: 'Afghanistan cannot win an election, but it might lose one'. ${ }^{20}$

Even the conservatives cannot count on all their members to vote in favour when Germany's Afghanistan mandate is renegotiated in December 2009. The party's support for the operation has eroded significantly. The Bavarian Christian Social Union (CSU) is particularly sensitive to sceptical popular opinion; almost every CSU member of parliament is elected by his or her district through a so-called direct mandate, and essentially has to face a Stammtisch - the politically opinionated regulars' table of a Bavarian pub 
- at home. Moreover, even among conservatives, the operation is often seen not as a German choice, but as a decision made by Americans to serve their own national interest. 'The war in Afghanistan is not seen as our war', said one senior CDU staffer. ${ }^{21}$

\section{The political picture}

Germany's military mission in Afghanistan began with a remarkable political showdown. On 11 September 2001, the German government declared 'uneingeschränkte Solidarität' (unlimited solidarity) with the United States. After NATO invoked Article V and the Afghanistan War was launched, Germany was prepared to join the operation. But then Chancellor Gerhard Schröder, a Social Democrat, faced considerable opposition in the Bundestag from his own governing coalition. Social Democrats and their Green partners did not wish to support their government in joining America - George W. Bush's America - at war in Afghanistan, although the conservative Christian Democrats and the liberal FDP would have guaranteed the necessary majority for the government. On 16 November 2001, Schröder decided to take a risky and highly unusual step: he called a vote of no confidence and tied his own fate to the Afghanistan vote, thereby confronting his red-green coalition with a choice between two evils, to topple their own government or support the Afghanistan mission. Schröder narrowly won, with four MPs of the Greens voting against the war for 'symbolic reasons', knowing that the government would survive. In hindsight, Schröder's move itself was symbolic: it showed that political support for the Afghanistan operation was fragile from the outset.

Political support for military operations matters greatly in Germany, perhaps more so than elsewhere. The Bundeswehr is often called a 'parliamentary force', a Parlamentsarmee. For historical reasons, the Bundestag has a constitutional responsibility to oversee operations. Perhaps in no other Western democracy is parliament involved in operational and even tactical questions to a similar extent. It is therefore extraordinarily important for German defence policy that the executive not only understands and manages the military situation in theatre, but that the defence minister manages the political game in Berlin, at times aggressively reaching out to a sceptical par- 
liament. The Bundestag is currently divided into five parliamentary groups, so-called Fraktionen. The strongest bloc is the conservatives, made up of the CDU and Bavaria's CSU. The second-largest group, on the centre-left, comprises the SPD. The remaining three parties vie for third place, moving in an 8 to $18 \%$ corridor: on the far-left Die Linke, and on the centre-left and centre-right respectively the Green Party and the FDP, which both cater to more educated and well-off voters.

Paradoxically, Germany's ambiguous reasons for being in Afghanistan make it easier for the established parties to support the operation. Many on the left support the war because they feel that Germany shares a moral responsibility for Afghanistan's future; on the right, support is justified in terms of self-defence and self-interest. The odd man out is Die Linke. This makes the new party on the far left an increasingly important element in Germany's Afghanistan policy: they are the only party that is unequivocally in favour of pulling out the Bundeswehr. The party argues that the US 'war on terror' has antagonised Afghans and Muslims worldwide, and has consequently contributed to making Germany and Europe less safe. However, the party is still treated as an outcast by the other parties, particularly the conservatives.

But the conservatives' own position is more complex than meets the eye. The German right is, at first glance, in favour of the operation and eager to ensure that Afghanistan does not turn into a launching pad for global terrorism. Upon closer inspection, however, the picture is more nuanced. Afghanistan is not Iraq, conservatives argue, and the template of a 'surge may not work there. The country is ethnically more complex, has no secular tradition, no resources or industrial base, no functioning and stable institutions, and little human capital. The goals of the Afghan operation are still seen as far too ambitious. The CDU's foreign-policy experts understand very well that talking to and co-opting 'conservative elements' in Afghanistan would mean that many girls could no longer attend school - a symbolic political issue in Germany. But more than that, some CDU politicians agree that Die Linke has a point: a number of conservative politicians privately concede that Afghanistan might be making Germany less secure, not more.22 
In consequence, critics of the mission in the Bundestag have steadily gained in strength since 2001. Germany's mandates for participation in both ISAF and Operation Enduring Freedom have to be confirmed annually by the Bundestag. On 13 November 2008 the Bundestag renewed Germany's commitment to Operation Enduring Freedom for 13 months. 428 members voted for a continuation, with 130 voting against, essentially the Greens and Die Linke. The maximum number of soldiers involved in the operation was reduced from 1,400 to 800 , and the allocation of 100 Special Operations Forces for Afghanistan was discontinued. Approval for the ISAF mandate, which is negotiated separately, has gone steadily down, although its confirmation has never yet been in serious jeopardy: in 2008, 442 out of 570 votes were for a continuation of the mandate, with 96 voting against and 32 abstentions. Among the conservatives, 201 cast votes to support the mandate, 5 members to oppose it, and 4 abstained. Among the Social Democrats, 180 supported it, 20 opposed it and 5 abstained. The FDP had 46 supporters and 6 opponents. The Green Party was almost evenly split, with 15 members in favour, 11 against and 23 abstaining. The only solid bloc was Die Linke, with 52 Nein votes.

\section{The military picture}

Long-time sceptics increasingly feel vindicated by events on the ground. The military situation in northern Afghanistan is getting tenser and more violent. For the last two years this ongoing trend has frustrated those German political leaders who were hoping they could keep the Afghan insurgency at arm's length.

Of all ISAF's five Regional Commands, the northern region was thought to be the most stable. This was mainly because the region's population is largely non-Pashtun and enjoys a relatively consolidated power structure. The north was the traditional power base of the Northern Alliance, the antiTaliban movement once led by Ahmed Shah Massoud. Mohammed Atta, a former warlord and subordinate commander of Massoud, had been a fierce opponent of the Taliban and is the incumbent strongman and governor in Balkh province, where Camp Marmal is located. Not least because of this alleged stability, Germany accepted the northern command in 2006. For the 
first few years the calculation paid off. Since 2006, the insurgency has been concentrated in the south and east of Afghanistan in the Pashtun heartlands. Some Germans started to believe that the situation in their area was better because the Bundeswehr's approach was less trigger-happy than that of their allies in southern areas. Hans-Ulrich Klose, a senior Social Democrat, reflected the view of many Germans when he suggested that 'America has contributed to a deteriorated situation in the south ${ }^{23}$ - implying that Germany had avoided a similar mistake in the north. But the insurgency is slowly creeping northwards and instability is affecting the north as it is the rest of the country. As some allies have occasionally felt compelled to remind their German colleagues, the north was never more secure because the Germans were there, but rather the Germans were in the north because it was more The insurgency secure. This is no longer the case.

In May 2007 a suicide attack on three German soldiers in the market square of Kunduz City signalled the beginning of the northern insurgency. Since then attacks on convoys and military bases have steadily increased. Insurgent forces initially relied on suicide attacks, improvised-explosivedevice attacks on convoys and rocket-propelled-grenade attacks on the PRTs. More recently they have staged ambushes and confronted ISAF forces openly. By June 2009 , the north was experiencing intense fighting. Kunduz province is at the centre of this confrontation. In parallel, over the last few years the insurgency has been increasingly successful in trying to extend its reach into regions of northern Afghanistan where ISAF's presence is relatively minimal, such as Baghlan and Faryab provinces.

The rate of combat fatalities has increased significantly. ISAF has reacted by readjusting its operational focus and enhancing its combat capabilities. Previously, the pattern of operational conduct in the north was limited predominantly to patrolling in the vicinity of bases. More recently a range of large-scale counter-insurgency operations has been conducted. Beginning with Operation Harekate Yolo II in autumn 2007 and followed by a range of subsequent operations, German commanders have decided to deploy ISAF forces in offensive 'clear-hold-build' operations against insurgents. ${ }^{24} \mathrm{Closely}$ 
tied to this is the issue of military assistance, with the build-up of Afghan security forces becoming an important focus of ISAF efforts over the last few years. Conducting offensive operations jointly with Afghan security forces is crucial for their successful build-up, since force-integration training drives the development of operational proficiency. At the same time, German authorities have reluctantly but continually enhanced combat capabilities in the north over the last few years. In retrospect, the decision in early 2007 to deploy Tornado reconnaissance aircraft marked the beginning of a trend to enhance combat capabilities of the German contingent. This was followed by decisions to redeploy Special Operations Forces (under ISAF mandate) from autumn 2007 and in 2008 to take over responsibility for ISAF Regional Command North's combat element, the Quick Reaction Force, from Norway in $2008 .{ }^{25}$

By mid 2009, military planners were seriously considering deploying mortar and howitzer capabilities to Afghanistan, which is something political and military leaders have been resisting strongly for the last few years. Operational commanders and their superiors have ordered units in the field to resort to a more aggressive force posture against insurgent units. Behind closed doors in Berlin there have been debates over whether - in the wake of the rearrangement of the overall ISAF command structure - the command structures of Regional Command North should be reorganised and enhanced, with the command post in the north being elevated from a one-star to a two-star position, supported by two deputy commanders, one for operations and one for stability. In an attempt to increase inter-agency cooperation, the deputy commander for stability could even be a civilian, possibly an ambassador. Upgrading the command post in the north to a two-star position would have to be accompanied by troop reinforcements, otherwise the idea might not be supported by Germany's allies. The ground is therefore being prepared for a potential expansion of Germany's engagement in northern Afghanistan. ${ }^{26}$ Such a reinforcement would be a strategically apt move against the background of a deteriorating situation in Pakistan, which has resulted in ISAF supply lines being moved to the north, giving the northern provinces added strategic significance. 
But Germany's ability to beef up its troops is limited. The German army presently has 17 infantry rifle battalions. Just maintaining the Quick Reaction Force keeps five battalions occupied; the military situation on the ground would require sending a second infantry rifle battalion. For quite some time, most elements of the Quick Reaction Force have been deployed in the Kunduz region, the hot spot in the north. As a result, the Regional Command North has no operational reserve and the force posture has become static. Deploying a second infantry rifle battalion would make it possible to increase the rate of joint operations with Afghan forces beyond Kunduz, for instance to enforce ISAF's presence in the province's remote northwestern region. But to do so would double the number of infantry units solely reserved for ISAF. Together with Germany's standing commitment to the NATO Response Force and the EU Battlegroups, the Afghan operation would then absorb almost all of Germany's infantry assets. Most of the military resources in urgent demand are already in critically short supply: there is an alarming shortage of tactical air-mobility capabilities, and the Bundeswehr is also short of medics and other crucial specialists. In short, increasing troop numbers and strengthening capabilities on the ground will not be easy.

A focus on numbers should not distract from a second shortcoming of German forces: the Bundeswehr is conceptually ill prepared for counterinsurgency. Only in May of this year could army thinkers present a draft of a very low-level paper on the German army's counter-insurgency doctrine to General Schneiderhan. Counter-insurgency, with its focus on population security, is a new concept for the Bundeswehr, an army that cut its teeth in Cold War manoeuvres focused on conventional-warfare scenarios. Within the Defence Ministry - and outside the realm of operations - the Afghanistan operation is widely seen as an odd exception and certainly not the kind of scenario military planners should prepare for in the long term. The Bundeswehr's established understanding of irregular warfare is much narrower and more enemy-centric than the broader, population-centred counter-insurgency approach favoured by other allies. 'It is more conventional and less political than counter-insurgency', says Winfried Nachtwei of the Greens. ${ }^{27}$ Yet junior, mid-level and senior commanders have learned 
much from their Norwegian, Swedish, Finnish and American counterparts in northern Afghanistan - and also from their own mistakes and the actions of an adaptive enemy. As in the United States, counter-insurgency in the institutional army is intuitively understood from the bottom up, not from the top down. Many German troops are tired of waiting to be victims; they want to be better prepared for combat. Some even feel ashamed because their hands are tied by tight legal rules and by what they see as bureaucratically minded senior officers.

In sum, field commanders are demanding troop enforcements for operational reasons. But the civilian and military hierarchy in the Ministry of Defence remains ambivalent both because of a lack of resources and a lack of political leadership. The ministry's military establishment remains reluctant to send more forces to Afghanistan when the actual politico-strategic reasoning for doing so is unclear. Generals are also acutely aware that the army lacks funding and adequate personnel for sustaining such an operation in the long run.

\section{Strong tensions, weak leadership}

For German policymakers, there are three principal options in Afghanistan: do more, do less, or continue as in the past with minor adjustments.

Doing more, particularly in the military sense, would be very costly politically. This applies not only to changing the number of troops deployed, but also the kinds of missions undertaken, the risk for Bundeswehr soldiers, and the mandated area of operation. Firstly, to do more would cost strategic flexibility. The Bundeswehr might on paper be a 250,000 -strong force, but in reality only a fraction of this number is deployable in warfare scenarios, as in Afghanistan. To be sure, Germany's parachute battalions are proficient in irregular warfare, but there are only four of them and all four are undermanned, lacking non-commissioned officers in particular. Germany's Special Operations Forces are among the Western world's specialoperations elite, but 300 deployable commandos overall is not very many. To tie more of these crucial combat resources to the Afghan operation would deny German authorities the option to provide forces for NATO or EU operations elsewhere. Secondly, to do more would require political willingness to 
order the military to shift its operational focus towards counter-insurgency, and to enable the army to do so by providing the necessary political and legal backing. In particular, the next mandate for ISAF would need to tackle the issue of legal limitations. As a next step, the structures for inter-agency cooperation would need to be drastically reformed both in the field and in Berlin. Finally, the necessary resources for the Afghan operation would have to be made available. All of this would demand a serious effort, and it is doubtful that Afghanistan will be high enough on the political agenda of the next German administration to bring this about.

Doing less, however, is also politically difficult, at least in the international arena. The United States has pledged an additional 21,00o troops for Afghanistan in 2009. Britain is punching far above its weight and has plans to bolster its 8,300 personnel in Afghanistan's hotly contested south, even though 206 British troops have already lost their lives. And France recently announced its intention to increase its own contribution to Afghanistan. Going against the mood and the Doing less is also politically difficult momentum in NATO is not something that German politicians would do lightly, not even the sceptical Social Democrats. But there is a view in the German strategic community that Washington is preparing for one last push in Afghanistan in order to leave in a few years' time. Some ask why Germany should engage more if this is the case. If the United States is preparing to leave in the mid term, Germany should prepare its exit strategy as well. Germany's reasons for being in Afghanistan, therefore, may be less focused on strategy or even national interests than on alliance solidarity. Chancellor Merkel did not push for a German NATO secretary-general to replace Jaap de Hoop Scheffer this year for two reasons: she didn't have a candidate, and she didn't want a candidate. A German NATO secretarygeneral would have made it politically more difficult to maintain a low profile in Afghanistan.

The slow erosion of patience among the German public is set to continue unless major developments interfere with the trend. There are two possible scenarios, one positive and one negative. The positive scenario is that the 'Afghan surge' works. If the level of violence in the south goes down, 
including US- and NATO-caused civilian casualties as well as Taliban attacks, then Germany might be in a position to increase its commitment to what would then be seen as a more realistic effort at reconstruction. In the mid term Germany's contribution would gain in strategic relevance due to the shifting of operational supply routes to the north and Germany's role as guardian of 'Route Pluto' through Kunduz and Baghlan provinces to guarantee supply lines from Uzbekistan to the Salang turnel.

The negative scenario is a major terrorist attack against German targets, either in Afghanistan or, worse, in Germany. There is no real way to prepare the population for a terrorist incident, and perhaps even politicians would find it difficult to cope: 'The political elite is not prepared for a terrorist attack', fears one senior official in the chancellery. ${ }^{28}$ Yet leaders across all parties are worried by the prospect of a terrorist incident in Germany or a successful major military operation by Taliban insurgents in northern Afghanistan. Their fear is that Germany might end up losing its will to fight as a result, of course only after a face-saving salvo of defiant statements in the face of terror.

Germany, in short, is trying to maintain a low profile by hiding politically behind bolder allies, rhetorically behind 'networked security' (a vague but often-used formula for force modernisation and improved civil-military relations) and geographically in what used to be a calmer north. But staying quiet on Afghanistan may prove a costly strategy for Germany. NATO's operation in Afghanistan risks motivating some of Europe's $16 \mathrm{~m}$ Muslims to go down the road of radicalisation. In 2009, Europol pointed out that 'the risk of an attack [in Europe] has increased for reasons that include military presence in Afghanistan'. ${ }^{29}$ The European Union is, for many reasons, more affected by this recoil effect than the United States, and consequently, its stakes are higher in Afghanistan. The longer a protracted occupation of large swathes of Afghanistan drags on, the more palpable and immediate the costs will be, while at the same time, the potential benefits will appear ever more vague and unrealistic. ${ }^{30}$ Keeping a low profile and reluctantly, if devotedly, following a sometimes strategically short-sighted American ally makes it more difficult for Berlin's decision-makers to shape the crucial debate about a new strategy for Afghanistan. 


\section{Notes}

1 Thomas L. Hughes, 'The German Mission to Afghanistan, 1915-1916", German Studies Review, vol. 25, no. 3, October 2002, p. 447-76.

2. Ministry for Economic Cooperation and Development (BMZ), March 2009, http:/www.bmz.de/de/laender/ partnerlaender/afghanistan/ zusammenarbeit.html.

3 Federal Ministry of the Interior, http:// www.bmi.bund.de/DE/Themen/ Sicherheit/Polizei/Afghanistan/ Afghanistan_node.html.

4 Federal Ministry of the Interior, 'Polizeiliche Aufbauhilfe in Afghanistan', I July 2009, http://www. bmi.bund.de/cln_144/DE/Themen/ Sicherheit/Polizei/Afghanistan/. Afghanistan.html.

5 Richard Holbrooke's assessment was that the Afghan police was 'underfunded, underpaid, undertrained, under-equipped, and easily corruptible'. The most important civilian programme, he said, was actually helping the enemy'. See 'Afghanistan: A Plan to Turn the Tide?', Hearing before the Committee on Foreign Relations, US Senate, Transcript, 31 January 2008 , pp. 60-1.

6 Deutscher Bundestag, 16 Wahlperiode, Drucksache 16/10473, 7 October 2008, pp. $4-5$.

7 Interview with senior chancellery official, Berlin, 12 June 2009.

8 Jerome Starkey, 'For us ze war is over by tea time, ja', Sunday Times, 18 November 2007.

9 Thomas Kröter, 'Krieg kommt in den Norden', Frankfurter Rundschau, 2 May 2009, p. 4 .
10 All casualty figures in this essay are from http:/casualties.org as of 24 August 2009.

11 See Statista, http://de.statista.com/ statistik/daten/studie/1546/umfrage/ ansicht-zu-bundeswehreinsaetzen-inafghanistan/.

12 Statista, http://de.statista.com/ statistik/daten/studie/1082/umfrage/ aufstockung-des-truppenkontingentsin-afghanistan/.

13 Statista, http://de.statista.com/ statistik/daten/studie/1277/umfrage/ deutsche-hilfe-im-kampf-gegen-denterror-auf-bitten-von-obama/\#info.

14 'Deutsche lehnen Afganistan-Einsatz ab', Cicero, 25 March 2009.

15 Otto Depenheuer, 'Was wir verteidigen', Frankfurter Allgemeine Zeitung, 26 February 2009, p. 8. Emphasis added.

16 Statista, http://de.statista.com/ statistik/daten/studie/2121/umfrage/ afghanistan---krieg-oderhumanitaerer-einsatz-derbundeswehr/

17 Interview with Hellmut Königshaus, Berlin, 15 June 2009.

18 Interview with Willy Wimmer, Berlin, 15 June 2009.

19 Interview with Rolf Mützenich, Berlin, 15 June 2009.

20 Interview with Winfried Nachtwei, Berlin, 15 June 2009.

21. Interview with senior CDU staffer, Berlin, 27 February 2009. See also Klaus Naumann, Einsatz ohne Ziel? (Hamburg: HIS Verlag, 2008).

22 Interviews with CDU staffers, Berlin, February and June 2009 .

23 Interview with Hans-Ulrich Klose, Berlin, 11 June 2009 . 
24 Timo Noetzel, 'Weniger Taschenkarten, mehr Wirkmittel. Afghanistan als Testfall für Deutschland und die NATO', Internationale Politik, vol. 63 , no. 3 , March 2008, p. 25-32.

25 Timo Noetzel and Martin Zapfe, 'Aufstandsbekämpfung als Auftrag. Instrumente und Planungsstrukturen für den ISAF-Einsatz' SWP-Studie/S 13, May 2008, pp. 5-22.

26 Thomas Kröter, 'Das Ministerium überlegt längst diskret, mehr deutsche Soldaten zu entsenden', Frankfurter Rundschau, 20 August 2009, p. 4 .
27 Interview withWinfried Nachwei, Berlihn, 15 June 2009 .

28 Interview with senior chancellery official, Berlin, 12 June 2009 .

29 Europol, TE-SAT 2009: EU Terrorism Situation and Trend Report, p. 17, http:// www.europol.europa.eu/publications/ EU_Terrorism_Situation_and_Trend_ Report_TE-SAT/TESAT2009.pdf.

30. For a detailed analysis of how counter-insurgency has limited value as a counter-terrorism strategy, see Thomas Rid, and Marc Hecker, War 2.o: Irregular Warfare in the Information Age (Westport CT: Praeger, 2009). 